\title{
Life-Cycle Monitoring of Long-Span PSC Box Girder Bridges through Distributed Sensor Network: Strategies, Methods, and Applications
}

\author{
Zheheng Chen, ${ }^{1}$ Tong Guo, ${ }^{1}$ and Shengyou Yan $^{2}$ \\ ${ }^{1}$ Key Laboratory of Concrete and Prestressed Concrete Structure, School of Civil Engineering, Ministry of Education, \\ Southeast University, Nanjing 210096, China \\ ${ }^{2}$ Jiangsu Province Communications Planning and Design Institute, Nanjing 210005, China
}

Correspondence should be addressed to Tong Guo; guotong77@gmail.com

Received 1 August 2014; Accepted 20 September 2014

Academic Editor: Ting-Hua Yi

Copyright (C) 2015 Zheheng Chen et al. This is an open access article distributed under the Creative Commons Attribution License, which permits unrestricted use, distribution, and reproduction in any medium, provided the original work is properly cited.

\begin{abstract}
Structural health monitoring (SHM) has attracted much attention in recent years, which enables early warnings of structural failure, condition assessments, and rational maintenance/repair strategies. In the context of bridges, many long-span steel bridges in China have been installed with the SHM systems; however, the applications of the SHM in prestressed concrete (PSC) bridges are still rather limited. On the other hand, the PSC box girder bridges are extensively used in highway and railway systems and premature damage of these bridges is often reported, resulting in considerable maintenance and/or replacement costs. First, this paper presents a state-of-art review on the SHM of long-span PSC bridges. Monitoring strategies, methods, and previous applications for these bridges are summarized and discussed. In order to well capture the behavior of the bridge during its whole life and to maximize the use of sensors, a life-cycle monitoring strategy is proposed, in which the sensor layout is determined according to requirements for construction monitoring, completion test, and in-service monitoring. A case study is made on a three-span PSC box girder bridge in China. The system configuration, sensor layout, and data communications, and so forth, are presented. The up-to-date monitored structural responses are analyzed and compared with the design values.
\end{abstract}

\section{Introduction}

Structural health monitoring (SHM) through distributed sensor network has attracted much attention in recent years [1-5], which enables early warnings of structural failure, condition assessments, and rational maintenance/repair strategies. In the context of bridges, many long-span steel bridges in China as well as in other parts of the world have been installed with the SHM systems; however, applications of the SHM in prestressed concrete (PSC) bridges are still rather limited. On the other hand, the PSC box girder bridges are extensively used in highway and railway systems, and premature damage of these bridges is often reported (i.e., cracks and excessive long-term deflections, etc.), resulting in considerable maintenance and/or replacement costs. Therefore, it is of great importance to develop a specific SHM system for the PSC bridges.
However, as compared with long-span steel bridges, there are several significant differences in the monitoring systems of the PSC bridges. First, the long-span steel bridges usually have longer main spans and are cable-supported; as a result, they are sensitive to vibration. Moreover, higher safety margin is often adopted in the design of supper long-span bridges, considering the catastrophic results or tremendous losses due to collapse. Besides, these bridges usually have high construction budget. For example, the Sutong Bridge [6], with a main span of $1,088 \mathrm{~m}$, costs about 1,450 million USD. Accordingly, it allows a more flexible budget on the SHM system, which is only a very small part of the total cost of the bridge. Therefore, a total number of 1,440 various sensors, that is, anemometers, accelerometers, strain gauges, displacement gauges, GPS, thermistors, humidity meter, clinometers, and corrosion gauges, and so forth, could be installed on the longspan steel bridges. 
As to the PSC bridges, they are usually shorter in spans (i.e., ranging from $50 \mathrm{~m}$ to $250 \mathrm{~m}$ ). Larger structural stiffness makes them much less sensitive to vibration. However, some time-dependent behaviors, including shrinkage and creep of concrete and stress relaxation of steel tendons, are important features of the PSC bridges, which result in the loss in prestress of tendons and increase in deflection. Besides, temperature gradient has a significant influence on the behavior of the PSC bridges. However, due to the limit on the construction budget and difficulties in monitoring, only a limited number of items could be monitored.

This paper reports the recent investigation on the SHM systems of long-span (i.e., with the main span of 100 to $300 \mathrm{~m}$ ) PSC bridges, and discussion is made on the monitoring strategies, methods, and existing applications. A life-cycle monitoring strategy is proposed, which covers the construction stage, completion test, and the service stage, so as to better capture the behavior of the bridge during its whole life and to maximize the use of sensors. A case study in China is provided to further demonstrate the feasibility of the proposed system.

\section{Monitoring Strategies, Methods, and Applications}

2.1. Monitoring Strategies. A brief summary of the monitoring items of PSC bridges all over the world in recent years [4-21] is provided in Table 1, where it is observed that the monitoring items vary due to different investigation purposes, bridge types, and budgets, and so forth. For example, according to the visual inspection on the Ferriby Road Bridge [12], a three-span skew reinforced concrete slab bridge, several defects were noted which may require maintenance in the future. Therefore, inclinometers were used on elastomeric bearings, and displacement transducers were installed across cracks on the soffit of the slab, which provide basis for the maintenance activities. After the famous collapse accident of the old I35W Bridge, the new I35W Bridge [7] was built, which consists of two prestressed concrete box girders in each traffic direction. To monitor the behavior of the new bridge, a large number of sensors were installed, including vibrating-wire strain gauges, thermistors, linear potentiometers, accelerometers, corrosion sensors, long-gauge fiber, and topography instruments, which monitor the local static strain, temperature, joint and bearings movements, vibrations, corrosion current, average strains, and global deformations, respectively. These sensors provide good data base for the study of long-term performance of the PSC bridges, such as creep, shrinkage, prestress loss, and long-term deflections. In 2008, the Federal Highway Administration (FHWA) launched the Long-Term Bridge Performance (LTBP) program [8], which intended to collect scientific-quality data from the Nation's highway bridges through a minimum 20 -year research effort. In the Utah State, several pilot bridges were selected, and sensors including velocity transducers, foil strain gauges, vibrating wire strain gauges, tilt meters, thermocouples, weather station, and traffic camera were installed. According to Table 1, deflection and temperature are the two most frequent monitoring items, followed by the strain, acceleration, and so forth. Although cracks, corrosion, and prestress loss are also important to PSC bridges, they are difficult to be monitored. Therefore, they are not frequently adopted as monitoring items. In general, the monitoring strategies should be determined according to the monitoring purpose, budget, and the feasibility of monitoring technologies. However, deflection and temperature are two basic monitoring items and should be included.

In addition to the in-service monitoring, monitoring and control on the construction stage and completion tests are also frequently conducted for large bridges, which provide valuable information of the bridges in various stages. However, in real practice, the monitoring in construction stage, completion tests, and service stage are usually separately conducted without sharing of sensors and information, which is waste of construction investment. On the other hand, the sensors used for construction monitoring and control may be well used in the subsequent stages (i.e., completion test and in-service monitoring). Monitored data (i.e., deflection, stress, etc.) in the construction stage and completion tests describe the initial status of the in-service monitoring. The loads in the completion tests are known so that the results of completion tests can be used to determine the major structural parameters and update the baseline finite element (FE) model, providing basis for health monitoring and damage identification in the service stage. Therefore, a lifecycle monitoring strategy is proposed, as shown in Figure 1, in which it is required that the monitoring in construction stage, completion tests, and service stage should be combined to minimize the monitoring costs and maximize the data utilization. In Figure 1, sharing of sensors, data, and condition parameters are illustrated through red, blue, and green lines, respectively.

2.2. Monitoring Methods. As shown in Table 1, deflection is one important monitoring item. Periodical measurement on the bridge through topography is an acceptable choice, but it is not continuous and costly. In the new I35W Bridge, longgauge fiber optic sensors were used to measure the strain distribution and thus to obtain the average curvature and deformed shape. However, this method requires the fibers to be adhered to the soffit of the girder, which is somewhat difficult in practice. Breakage of fibers and the long-term durability are also concerns of such a method.

On the Jiangjin Yangtze River Highway Bridge with a main span of $240 \mathrm{~m}$, laser video deflection measurement system (LVDMS) was used to monitor the long-term deflection [20]. As deflection at the measuring point occurs, the light spots projected to the projection target move in the opposite direction; see Figure 2(a). The spots shot by the camera can thus be digitalized and be input to the computer to calculate the displacement relative to the fixed point. However, when there are a number of measuring points, multiple laser transmitters must be installed at multiple fixed points of the bridge while it is usually difficult to find so many appropriate installation positions in practice. Similar application was made on the Alwen Bridge [21], where the noncontact Weighted-Stretched-Wire System (NWSWS) was adopted for deflection monitoring. As shown in Figure 2(b), 
TABLE 1: Summary of monitoring items on PSC bridges.

\begin{tabular}{|c|c|c|c|c|c|c|c|c|c|c|}
\hline \multirow[b]{2}{*}{ Bridge name } & \multicolumn{10}{|c|}{ Monitoring Items } \\
\hline & Strain & $\begin{array}{l}\text { Deflection } \\
\text { or rotation }\end{array}$ & $\begin{array}{c}\text { Support } \\
\text { displacement }\end{array}$ & $\begin{array}{l}\text { Acceleration } \\
\text { or velocity }\end{array}$ & Corrosion & Crack & $\begin{array}{c}\text { Prestress } \\
\text { loss }\end{array}$ & $\begin{array}{c}\text { Traffic } \\
\text { camera }\end{array}$ & Temperature & $\begin{array}{l}\text { Weather } \\
\text { station }\end{array}$ \\
\hline $\begin{array}{l}\text { Ferriby Road } \\
\text { Bridge (UK) }\end{array}$ & & $\sqrt{ }$ & & & & $\sqrt{ }$ & & & & \\
\hline $\begin{array}{l}\text { PI-57 Bridge } \\
\text { (France) }\end{array}$ & & & & $\sqrt{ }$ & & & & & $\sqrt{ }$ & \\
\hline $\begin{array}{l}\text { Lezíria Bridge } \\
\text { (Portugal) }\end{array}$ & $\sqrt{ }$ & $\sqrt{ }$ & $\sqrt{ }$ & & & & & & $\sqrt{ }$ & \\
\hline $\begin{array}{l}401 \text { Southbound } \\
\text { Bridge (USA) }\end{array}$ & $\sqrt{ }$ & $\sqrt{ }$ & $\sqrt{ }$ & & & & $\sqrt{ }$ & & $\sqrt{ }$ & \\
\hline $\begin{array}{l}\text { California Pilot } \\
\text { Bridge (USA) }\end{array}$ & $\sqrt{ }$ & $\sqrt{ }$ & & $\sqrt{ }$ & & & & $\sqrt{ }$ & $\sqrt{ }$ & \\
\hline $\begin{array}{l}\text { Utah Pilot Bridge } \\
\text { (USA) }\end{array}$ & $\sqrt{ }$ & $\sqrt{ }$ & & $\sqrt{ }$ & & & & $\sqrt{ }$ & $\sqrt{ }$ & $\sqrt{ }$ \\
\hline $\begin{array}{l}\text { Kishwaukee Bridge } \\
\text { (USA) }\end{array}$ & $\sqrt{ }$ & & & $\sqrt{ }$ & & $\sqrt{ }$ & & & $\sqrt{ }$ & \\
\hline $\begin{array}{l}\text { New I35W Bridge } \\
\text { (USA) }\end{array}$ & $\sqrt{ }$ & $\sqrt{ }$ & $\sqrt{ }$ & $\sqrt{ }$ & $\sqrt{ }$ & & & & $\sqrt{ }$ & \\
\hline $\begin{array}{l}\text { Kamikazue } \\
\text { Viaduct (USA) }\end{array}$ & & & & & & & $\sqrt{ }$ & & & \\
\hline $\begin{array}{l}\text { A curved bridge } \\
\text { (USA) }\end{array}$ & & $\sqrt{ }$ & & $\sqrt{ }$ & & & & & $\sqrt{ }$ & \\
\hline $\begin{array}{l}\text { West Street } \\
\text { On-ramp Bridge } \\
\text { (USA) }\end{array}$ & & & & $\sqrt{ }$ & & & & & & \\
\hline $\begin{array}{l}\text { North Halawa } \\
\text { Valley Viaduct } \\
\text { (USA) }\end{array}$ & & $\sqrt{ }$ & $\sqrt{ }$ & & & & & & & \\
\hline $\begin{array}{l}\text { Zhaoqing Xijiang } \\
\text { Bridge (China) }\end{array}$ & $\sqrt{ }$ & & & & & & & & $\sqrt{ }$ & \\
\hline $\begin{array}{l}\text { Chongqing } \\
\text { Shibanpo Bridge } \\
\text { (China) }\end{array}$ & $\sqrt{ }$ & $\sqrt{ }$ & & & & & & & $\sqrt{ }$ & \\
\hline $\begin{array}{l}\text { Xushuigou Bridge } \\
\text { (China) }\end{array}$ & $\sqrt{ }$ & $\sqrt{ }$ & & & & & & & $\sqrt{ }$ & \\
\hline $\begin{array}{l}\text { Jiangjin Yangtze } \\
\text { River Highway } \\
\text { Bridge (China) }\end{array}$ & $\sqrt{ }$ & $\sqrt{ }$ & & & & $\sqrt{ }$ & & & $\sqrt{ }$ & \\
\hline $\begin{array}{l}\text { Anwen Bridge } \\
\text { (China) }\end{array}$ & & $\sqrt{ }$ & & & & & & & $\sqrt{ }$ & \\
\hline $\begin{array}{l}\text { Monitored items in } \\
\text { total }\end{array}$ & 9 & 12 & 4 & 7 & 1 & 2 & 2 & 2 & 12 & 1 \\
\hline
\end{tabular}

the camera fixed on the bridge moves as deflection occurs, so that the projection of the stretched-wire changes correspondingly. The deflection can thus be obtained by recording and analyzing such movements. Due to that the elevations of the soffits at midspan and piers of long-span PSC bridges vary considerably, installation and maintenance of such systems may be difficult.

On the Jinghang Canal Bridge, as to be presented in detail, a vertical displacement transducer (DT) was adopted to measure the long-term deflection of bridge, based on a hydrostatic leveling system and the application of the communicating vessels principle to an internal hydraulic system, filled with antifreeze fluid, which is installed along the bridge and reaches the relevant points where the relative vertical displacement is going to be measured. As shown in Figures 2(c) and 2(d), this hydraulic system, in hydrostatic equilibrium, allows the monitoring of the structure's deformed shape through the measuring of the apparent liquid level height at given points and comparing it with reference points where the vertical displacement can be neglected. To avoid the evaporation of the fluid, silicon oil was placed on its surface. The resolution and measurement precision are $0.01 \mathrm{~mm}$ and $0.1 \mathrm{~mm}$, respectively. Similar displacement monitoring system has been used on the Lezíria Bridge [9]. 


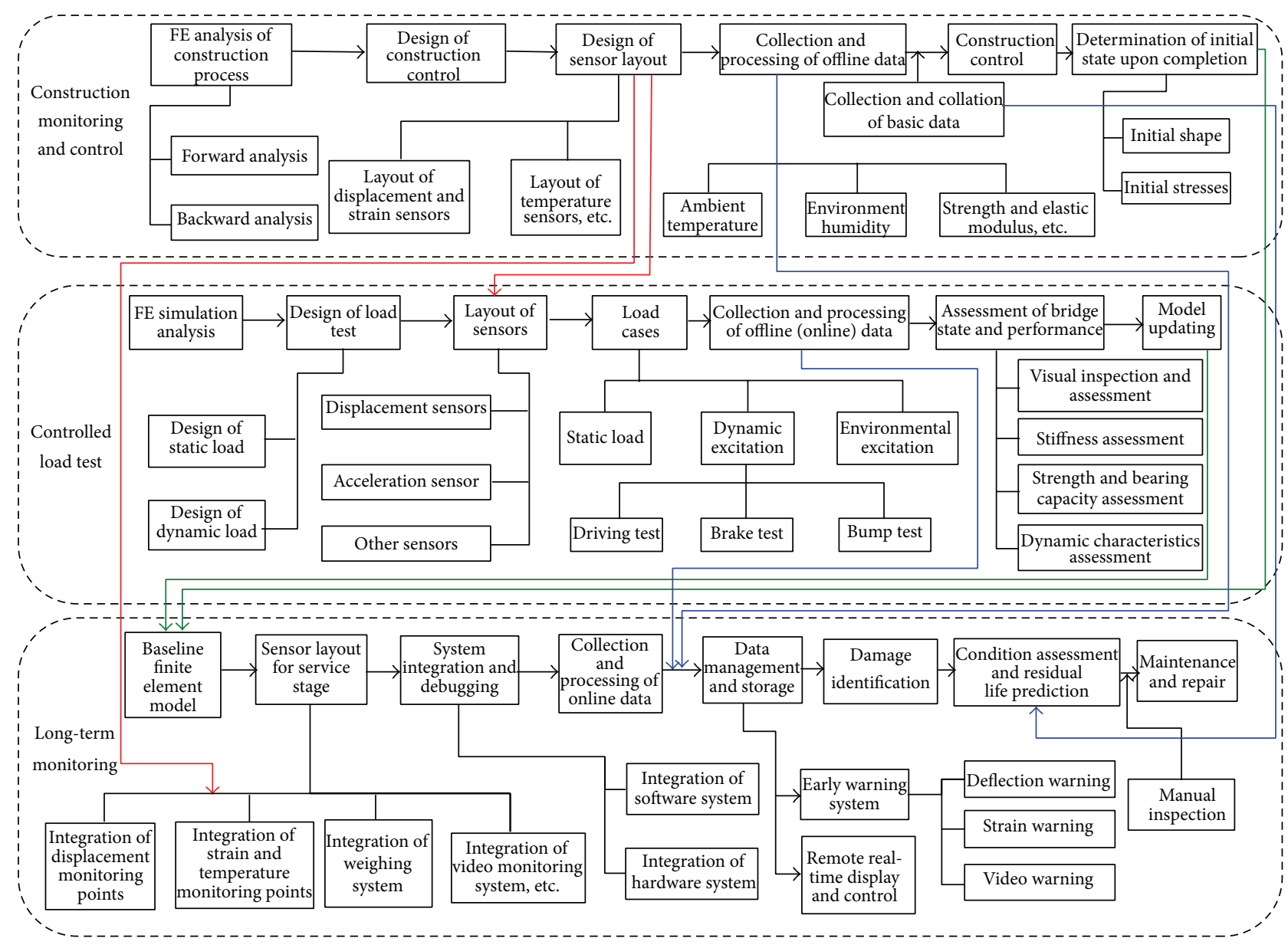

FIGURE 1: Life-cycle monitoring of PSC bridges.

As to the monitoring of prestress loss, most existing applications are for the external tendons. The most commonly used method to measure the posttensioning tendon stress is by attaching strain gages to the strands that form the tendons. However, this method is not applicable when the epoxy-coated strands are used for tendons. For the unbonded tendons, load cell at the ends of anchorage is also an efficient way to monitor the forces. On the US 401 Southbound Bridge [10], which utilized prestressed high performance concrete (HPC) girders, load cells were adopted at the anchorage ends to measure the time-dependent tendon forces; however, the forces at certain points of the tendon cannot be measured using this method. In recent years, the elastomagnetic (EM) sensing has been developed as a nondestructive testing technology, which is based on the elastomagnetic effect of ferromagnetic materials. Subject to external forces, strains or stresses develop in the ferromagnetic material, resulting in the change in magnetic permeability. Thus, the variation in tendon forces can be measured through the measurement on magnetic permeability, as shown in Figure 3. The beneficial features of the EM sensors include (1) noncontact measurement so that the influence on the structure is minimized; (2) rapid response, desirable precision, and reliability; (3) longterm and long-distance monitoring, and (4) monitoring on bonded tendons at multiple cross sections. Pilot study was made on the Kishwaukee River Bridge [11] (with unbonded tendons) and some bridges in China (with bonded tendons).

Monitoring on cracks is also an important measure to know the evolution of such defects on bridges. Two linear potentiometric displacement transducers (LPDTs) are usually used for such measurements. One of the LPDTs is placed across a crack on the deck soffit and the other is placed across an uncracked region of concrete for temperature compensation [12]. However, this method is only applicable to existing cracks, and only one point could be measured. Recently developed optical fiber based technologies, however, bring possibility to the distributed monitoring by placing the fibers along the concerned area. Existing methods include the BOTDR, the BOTDA (or the PPP-BOTDA), and the longgauge FBG sensors. Higher resolution and better durability are required for these methods to be applied in real monitoring projects rather than laboratory tests and pilot studies.

Considering that the monitoring of PSC bridges is usually subjected to limited budget, an efficient data collecting and transportation way is required. In this regard, wireless network is more appealing than traditional wire-based methods, as shown in Figure 4. However, the amount of data is also limited. Therefore, data are usually collected and sent in a static or quasistatic way with a relatively low frequency, ranging from $1 / 60 \mathrm{~Hz}$ to $1 / 600 \mathrm{~Hz}$. In addition, there is not 


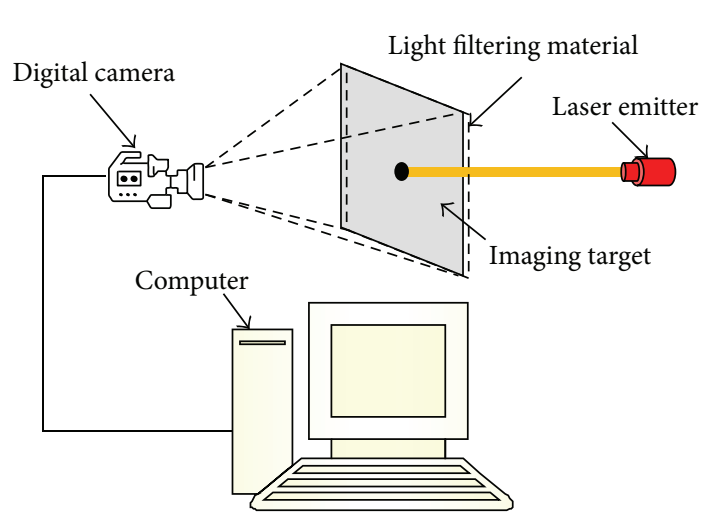

(a) The LVDMS

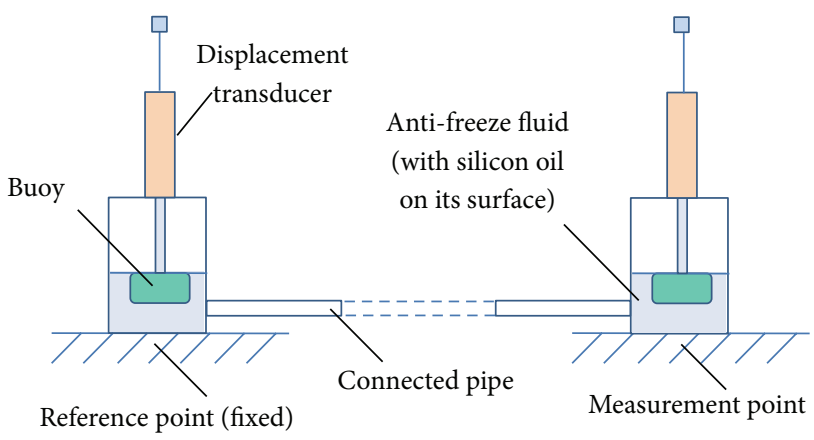

(c) Schematic representation of the hydrostatic leveling system

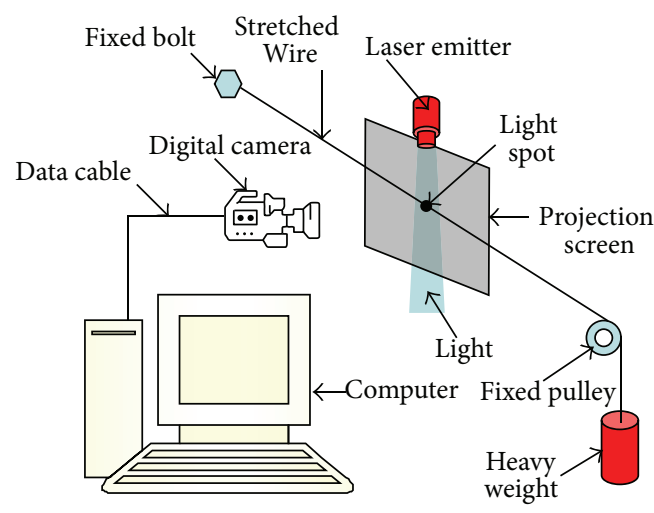

(b) The NWSWS

FIGURE 2: Several deflection monitoring systems.

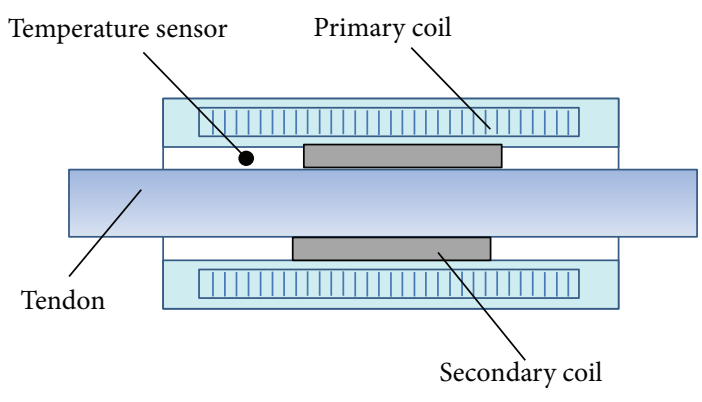

(a) Schematic representation of the EM sensor

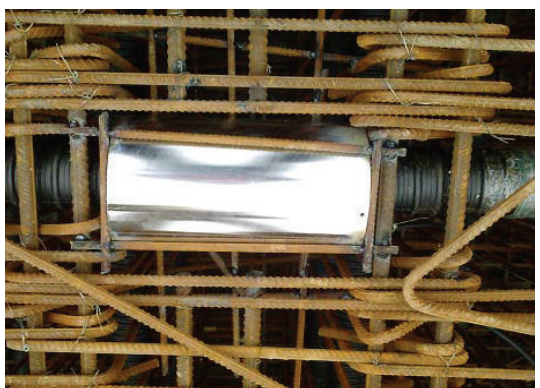

(b) Field installation

FIgURE 3: Prestress monitoring using EM sensors.

usually a specific monitoring room near these bridges for power supply. Batteries or solar panels are often used instead. However, it is also a good choice to utilize the power from the road lighting system.

Other monitoring items, such as strain, temperature, acceleration, support displacements and corrosion, have been extensively applied and therefore are not repeated here.

\section{Case Study}

3.1. Bridge under Investigation. The Jinghang Canal Bridge (JCB) is a three-span PSC bridge in Suzhou, China. It has one main span of $150 \mathrm{~m}$ and two side spans of $85 \mathrm{~m}$, respectively,

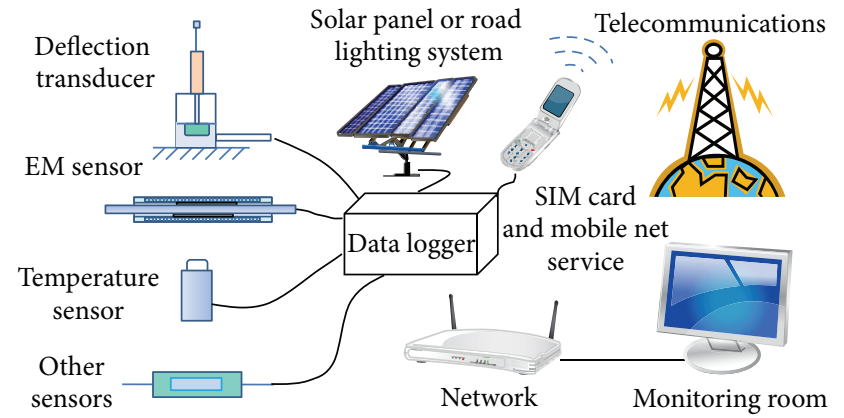

FIGURE 4: Configuration of the monitoring system using wireless network. 


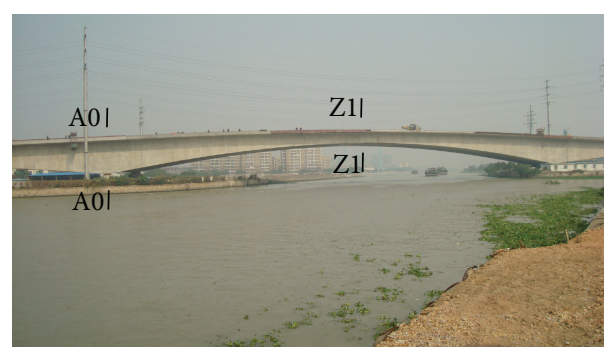

(a) Photograph of the bridge at completion

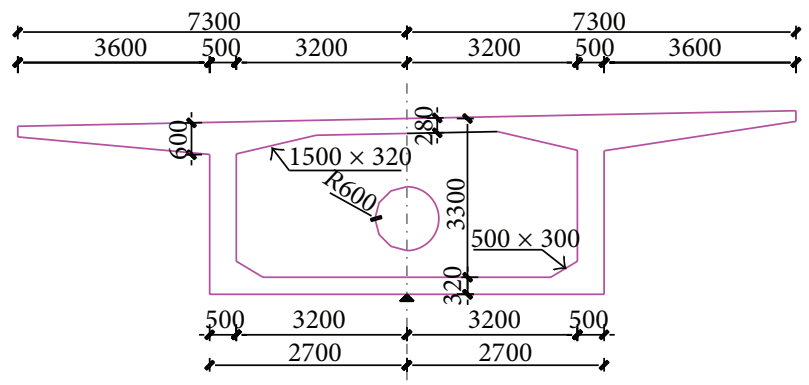

(b) Z1 section

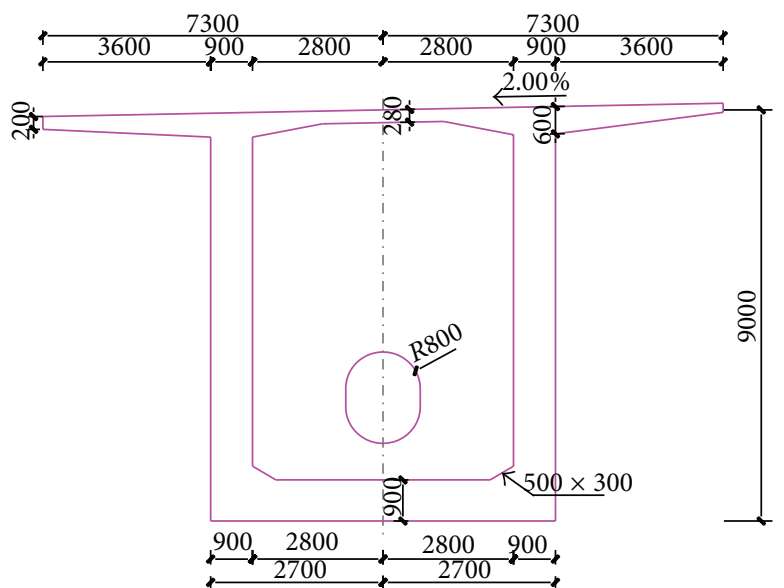

(c) A0 cross section

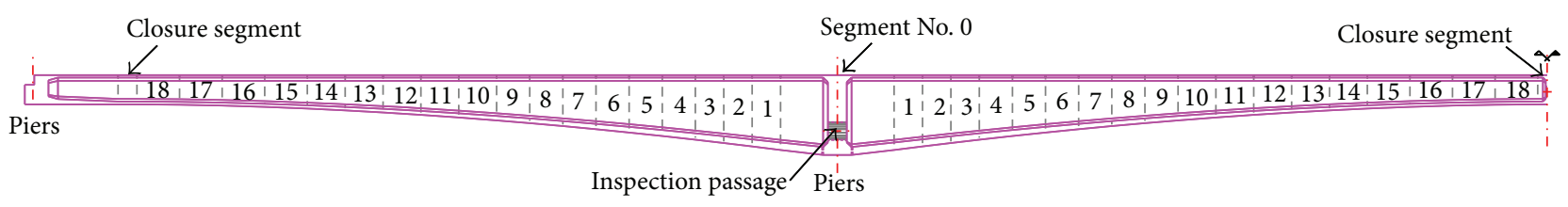

(d) Serial number of segments

FIgure 5: Profile and cross sections of the Jinghang Canal Bridge (dimensions in $\mathrm{mm}$ ).

as shown in Figures 5(a), 5(b), and 5(c). The bridge consists of two separated single-cell box girders in two traffic directions. The top slab of the girder has a total width of $14.6 \mathrm{~m}$ and the length of its cantilever is $3.6 \mathrm{~m}$. The width of the bottom flange is $7.4 \mathrm{~m}$ and its thickness varies from $90 \mathrm{~cm}$ at the supports to $32 \mathrm{~cm}$ at the midspan. The height of box girder ranges from $9.0 \mathrm{~m}$ at the supports to $3.3 \mathrm{~m}$ at the midspan. The web thickness ranges in steps from $90 \mathrm{~cm}$ at the supports to $50 \mathrm{~cm}$ at the midspan. The main structure was completed on October 29, 2013 and the pavement construction was added by December 15, 2013. The bridge was open to traffic in January, 2014. Figure 5(d) shows the arrangement of the box girder and the Table 2 shows the detailed construction process of the bridge.

According to the monitoring strategy depicted in Section 2, the sensor layout for the monitoring in construction, completion test, and service stages is determined, as shown in Figure 6. In the construction stage, the stresses, and elevations are the emphasis. The construction process of superstructure, as listed in Table 2, lasted for about 237 days. As shown in Figure 6, the across sections with relatively large longitudinal stresses were selected for monitoring, where sections A1 to A4 are at the end of the segment number 0 , sections $\mathrm{B} 1$ and $\mathrm{B} 2$ are at the middle of the side spans, and sections $\mathrm{Z1}, \mathrm{Z} 2$, and $\mathrm{Z} 3$ are at the midspan and $1 / 4$ span of the main span, respectively. During the completion tests, the stresses sensors for construction monitoring were used, and acceleration sensors were installed to measure the dynamic responses. As to the long-term monitoring, the items include the temperature, strain of reinforcement, and deflections, as shown in Figure 6. In order to minimize the cost of the system, long-term monitoring of temperature and strains utilized some sensors embedded in the bridge for construction monitoring. These sensors are vibrating string gauges with built-in temperature couples, so that strain and temperature can be measured at the same time. The data were collected automatically through the JMBV-8A acquisition module, as shown in Figure 7, and each module has eight channels. The data were collected with a 10 min interval, that is, a sampling rate of $1 / 600 \mathrm{~Hz}$.

The long-term deflection monitoring used the hydrostatic leveling system, as shown in Figures 2(c), 2(d), and 7(b). Six cross sections were selected for monitoring, including the midspan and $1 / 4$ span of the main span and the side span, 


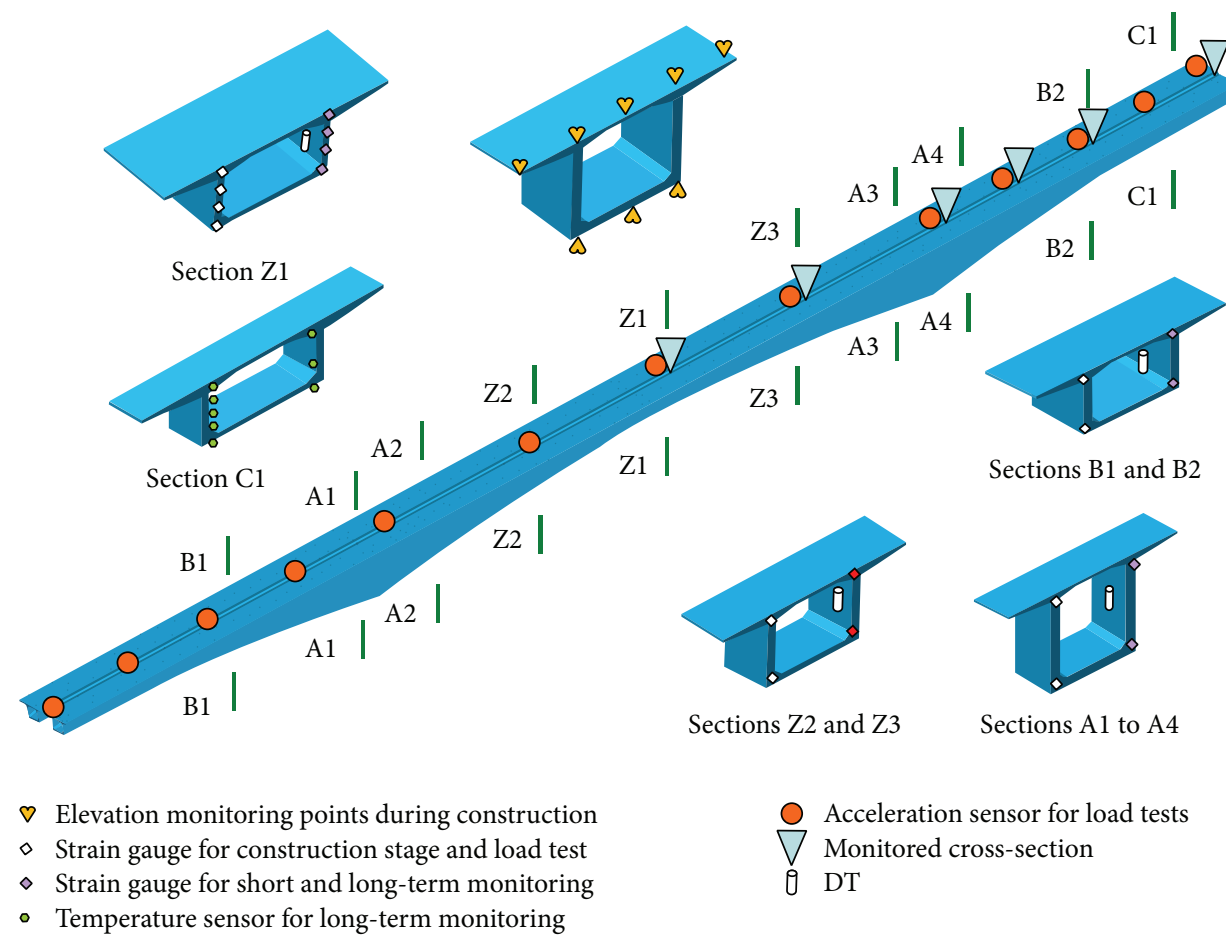

FIGURE 6: Configuration of the monitoring system.

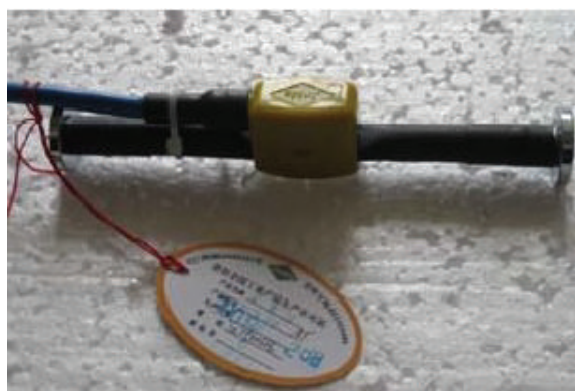

(a) JMZX-215 strain gauge

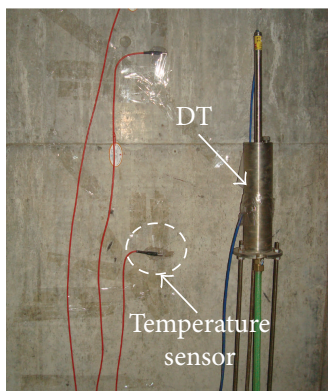

(b) Temperature and deflection sensors

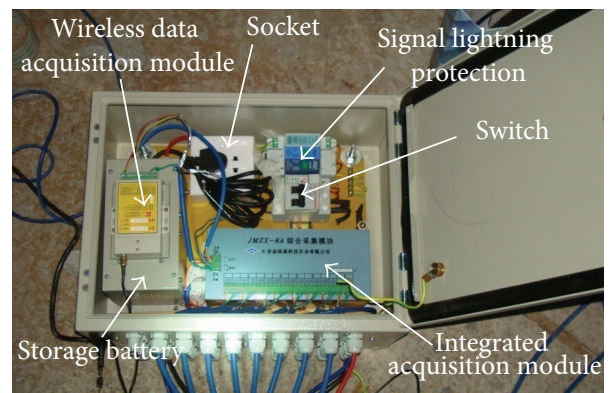

(c) Data logger

FIgURE 7: Sensors for long-term monitoring.

and two reference cross sections at the piers of main span and side span. Considering the longitudinal slope of this bridge is high (4\%), it is not possible to place all the six measuring points at the same elevation. Therefore, two separate systems were adopted. Measuring points at the midspan and 1/4 span of the main span and its support are of the same elevation, while points at the midspan and 1/4 span of the side span and its support are of the same elevation. Each DT was installed on the inner surface of the web of the box girder, as shown in Figure 6. All the measuring points, however, were collected in series through one power cable and one signal cable, and they are finally collected to the bus interface module. All the data were finally sent to the monitoring room at the Southeast University hundreds kilometers away from the bridge site in a wireless way, as shown in Figure 4 . The power of the SHM system is supplied by the road lighting system. The total SHM system is very cheap as compared with those on the longspan steel bridges. Not including the sensors for construction monitoring, the total cost is only about 30 thousand US dollars.

3.2. Monitoring in the Construction Stage. According to Figures 8(a) and 8(b), the monitored stresses agree with the design values. The largest difference between the stresses in the top plates at the upstream side and the design values is $2.23 \mathrm{MPa}$, which occurred when the segment number 14 was cast, while the largest difference at the downstream side is $2.05 \mathrm{MPa}$, which occurred as the segment number 7 was cast. The largest differences between the stresses at the bottom plates and the design values are $1.92 \mathrm{MPa}$ and 2.06 $\mathrm{MPa}$, respectively, which occurred during the closure of bridge at midspan. After the completion of main girder, 

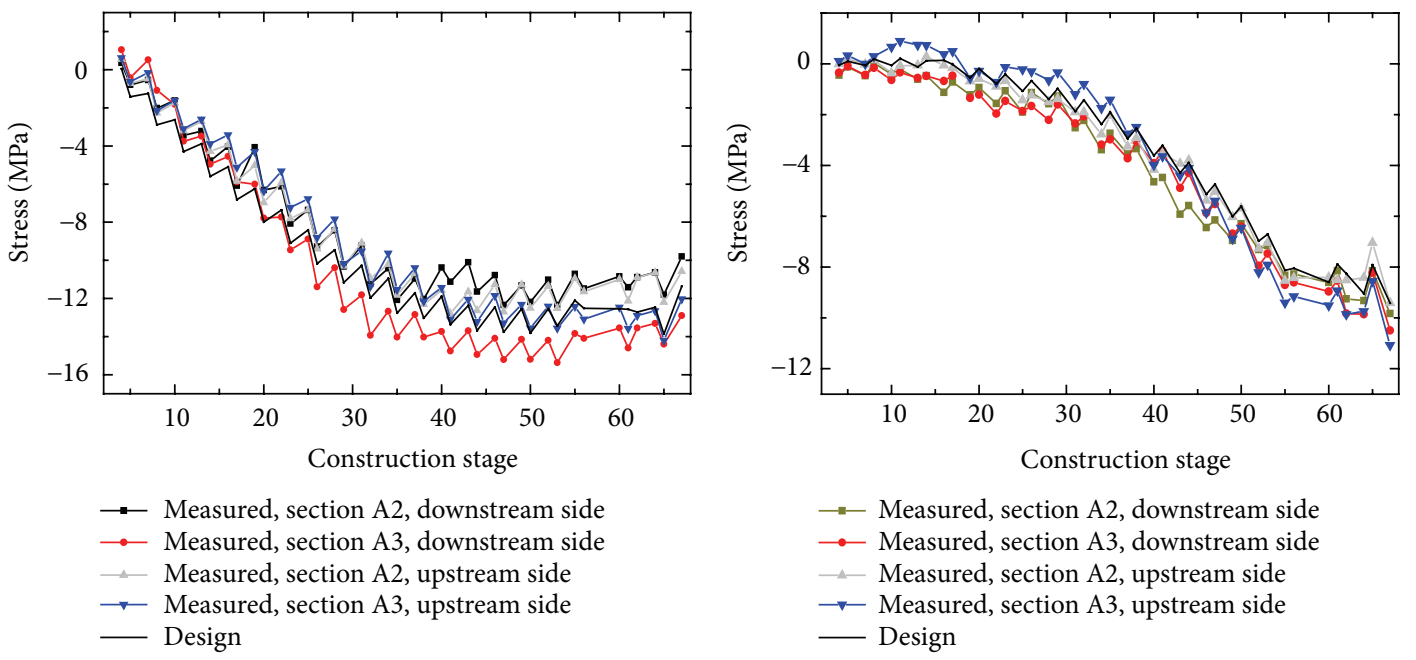

(b) Bottom plates, segment number 0
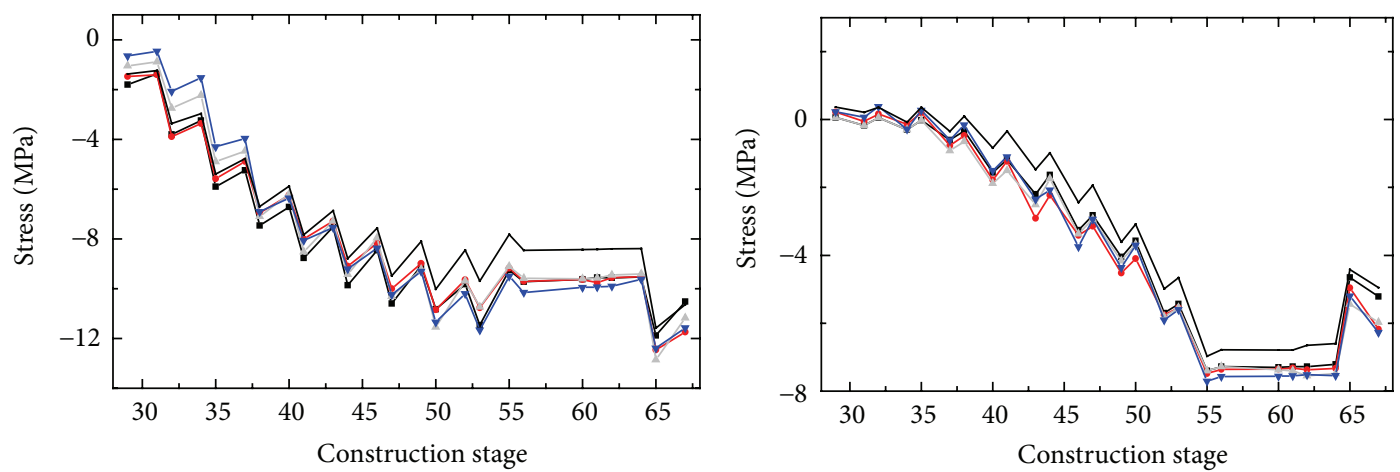

-- Measured, section Z2, downstream side

-•- Measured, section Z3, downstream side

- - - Measured, section Z2, upstream side

- v- Measured, section Z3, upstream side

-•- Design

(c) Top plates, at 1/4 span of main span
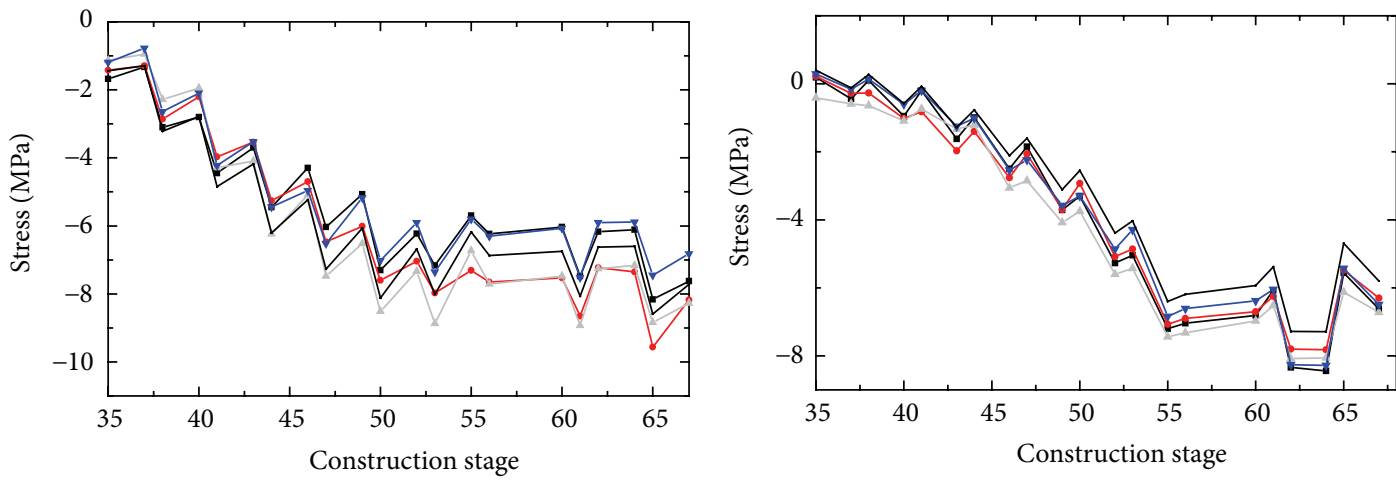

$\rightarrow$ Measured, section B1, downstream side

- Measured, section B2, downstream side

$\because$ Measured, section B1, upstream side

$\rightarrow$ Measured, section B2, upstream side

— Design

(e) Top plates, at midspan of side span

--- Measured, section Z2, downstream side

-.- Measured, section Z3, downstream side

-A- Measured, section Z2, upstream side

$-v-$ Measured, section Z3, upstream side

-•- Design

(d) Bottom plates, at midspan of main span

- Measured, section B1, downstream side

- Measured, section B2, downstream side

$\rightarrow$ Measured, section B1, upstream side

$\rightarrow$ Measured, section B2, upstream side

- Design

(f) Bottom plates, at midspan of side span

Figure 8: Stresses in various construction stages. 
TABLE 2: Construction process of superstructure of the Jinghang Canal Bridge.

\begin{tabular}{|c|c|c|c|}
\hline Construction stage & Construction contents & Duration (day) & $\begin{array}{c}\text { Cumulated } \\
\text { time (day) }\end{array}$ \\
\hline 1 & Concrete casting of segment number 0 & 11 & 11 \\
\hline 2 & Jacking of tendons in segment number 0 & 1 & 12 \\
\hline 3 & $\begin{array}{l}\text { Temporary consolidation and installation of hanging } \\
\text { baskets }\end{array}$ & 3 & 15 \\
\hline 4 & Concrete casting of segment number 1 & 7 & 22 \\
\hline 5 & Jacking of tendons in segment number 1 & 1 & 23 \\
\hline 6 & Moving forward of hanging baskets & 1 & 24 \\
\hline 7 & Concrete casting of segment number 2 & 7 & 31 \\
\hline 8 & Jacking of tendons in segment number 2 & 1 & 32 \\
\hline 9 & Moving forward of hanging baskets & 1 & 33 \\
\hline 10 & Concrete casting of segment number 3 & 7 & 40 \\
\hline 11 & Jacking of tendons in segment number 3 & 1 & 41 \\
\hline 12 to 54 & Concrete casting of segments number 4 to number 17 & 12 per segment & 160 \\
\hline 55 & Concrete casting of segment number 18 & 7 & 167 \\
\hline 56 & Jacking of tendons in segment number 18 & 1 & 168 \\
\hline 57 & $\begin{array}{l}\text { Concrete casting of straight segments in both side spans } \\
\text { using brackets }\end{array}$ & 1 & 170 \\
\hline 58 & $\begin{array}{l}\text { Converting hanging baskets into hoisting baskets in } \\
\text { side spans }\end{array}$ & 2 & 172 \\
\hline 59 & $\begin{array}{l}\text { Counterweight of water tank in both side spans and } \\
\text { central span, and installation of stiff steel framework. }\end{array}$ & 1 & 173 \\
\hline 60 & $\begin{array}{l}\text { Casting of closure segments in side spans and removal } \\
\text { of counterweight }\end{array}$ & 7 & 180 \\
\hline 61 & Jacking of closure tendons in side spans & 3 & 183 \\
\hline 62 & $\begin{array}{l}\text { Removal of brackets in side spans and temporary } \\
\text { consolidation }\end{array}$ & 4 & 187 \\
\hline 63 & $\begin{array}{l}\text { Converting hanging baskets into hoisting baskets in } \\
\text { main spans }\end{array}$ & 2 & 191 \\
\hline 64 & $\begin{array}{l}\text { Concrete casting of closure segment in main span and } \\
\text { removal of counterweight }\end{array}$ & 7 & 198 \\
\hline 65 & Jacking of closure tendons in central span & 3 & 201 \\
\hline 66 & $\begin{array}{l}\text { Removal of hoisting baskets in both side and main } \\
\text { spans }\end{array}$ & 1 & 202 \\
\hline 67 & Construction of bridge deck pavement & 35 & 237 \\
\hline
\end{tabular}

the cross sections have relatively large compressive stresses, which provide desirable conditions for the bridge service.

Figures $8(\mathrm{c})$ and $8(\mathrm{~d})$ show the monitored stresses at the 1/4 spans of the main span. The largest differences between monitored stress and design values are $1.77 \mathrm{MPa}$ and $1.98 \mathrm{MPa}$ for top plates at upstream and downstream sides, respectively, which both occurred as the tendons in segment number 17 were jacked. The stress differences in bottom plates at the upstream and downstream sides are within $1 \mathrm{MPa}$. In general, the top plates have larger compressive stresses than the bottom plates.

As to the midspan cross section of the side spans, the comparison between monitored data and calculation is illustrated in Figures 8(e) and 8(f). The largest differences of the stress in the top plates at the upstream and downstream sides are 1.24 MPa and 1.14 MPa, which occurred at the jacking of tendons in segment number 15 and the closure of the bridge, respectively. For the bottom plates, the largest differences are $1.15 \mathrm{MPa}$ and $1.44 \mathrm{MPa}$, respectively, which both occurred at the closure of the bridge.

The alignment control of the bridge is an important job which is conducted by controlling the elevations of segments dynamically during the construction process. As shown in Figure 6, there are three monitoring points at the top and bottom plates, respectively, to monitor the deflections, and two monitoring points at two slabs to control the torsion during the construction. For each segment, elevation monitoring is conducted during the installation of form work, before and after concrete casting, before and after jacking of tendons. Through error analysis, the elevation of the next segment is determined. Figure 9 shows the differences in monitored and design elevations upon closure of the bridge, where the largest 
TABLE 3: Description of load cases.

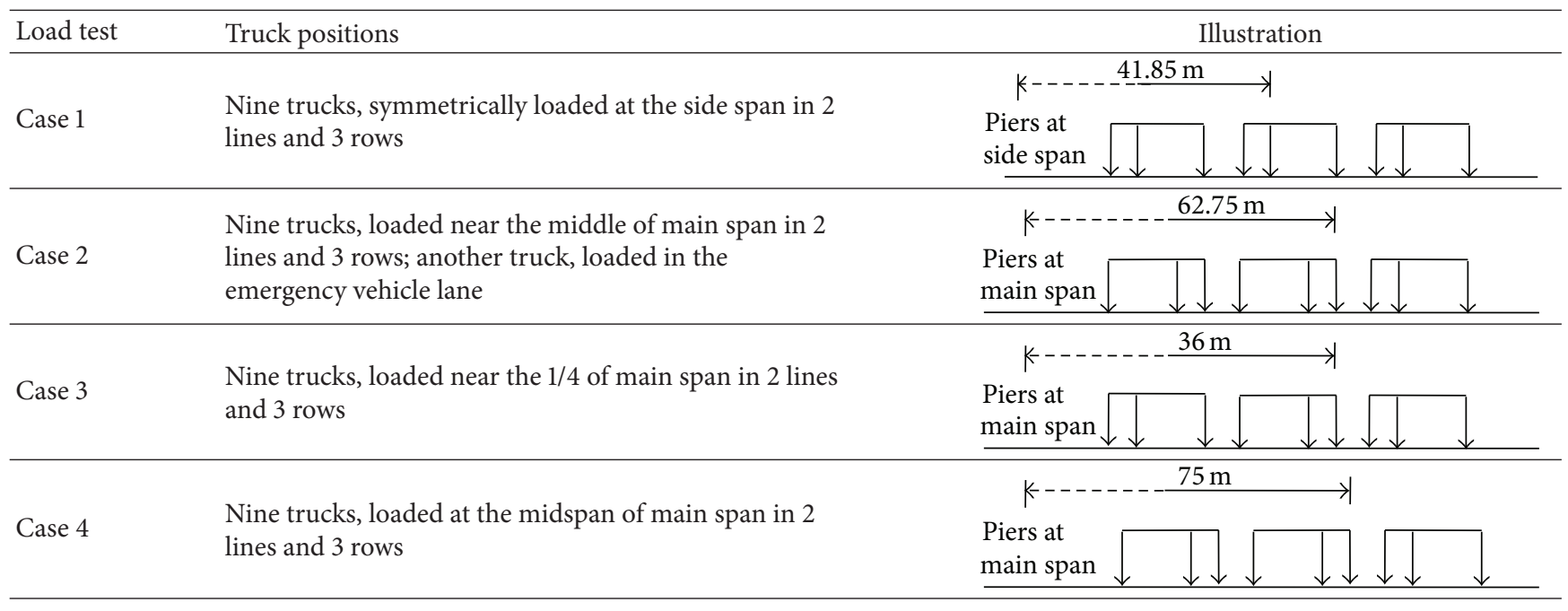

TABLE 4: Stress analysis of test results (upstream).

\begin{tabular}{|c|c|c|c|c|c|c|c|c|}
\hline Load test & $\begin{array}{l}\text { Monitored } \\
\text { section }\end{array}$ & Position & $\begin{array}{l}\text { Total stress } \\
\text { (MPa) }\end{array}$ & $\begin{array}{l}\text { Elastic stress } \\
\quad(\mathrm{MPa})\end{array}$ & $\begin{array}{c}\text { Theoretical } \\
\text { stress } \\
(\mathrm{MPa})\end{array}$ & $\begin{array}{c}\text { Residual } \\
\text { stress } \\
(\mathrm{MPa})\end{array}$ & $\begin{array}{l}\text { Check } \\
\text { coefficient }\end{array}$ & $\begin{array}{l}\text { Relative residual } \\
\text { stress (\%) }\end{array}$ \\
\hline \multirow{2}{*}{ Case 1} & \multirow{2}{*}{$\mathrm{B} 1$} & Top flange & -1.00 & -0.96 & -1.90 & -0.04 & 0.51 & 4.26 \\
\hline & & Bottom flange & 1.64 & 1.5 & 2.60 & 0.14 & 0.58 & 8.53 \\
\hline \multirow{2}{*}{ Case 2} & \multirow{2}{*}{$\mathrm{A} 1$} & Top flange & 0.22 & 0.2 & 1.40 & 0.02 & 0.14 & 7.42 \\
\hline & & Bottom flange & -1.21 & -1.08 & -1.50 & -0.13 & 0.72 & 10.40 \\
\hline \multirow{2}{*}{ Case 3} & \multirow{2}{*}{$\mathrm{Z1}$} & Top flange & -0.56 & -0.48 & -0.90 & -0.08 & 0.53 & 14.65 \\
\hline & & Bottom flange & 0.67 & 0.62 & 1.10 & 0.05 & 0.56 & 7.51 \\
\hline \multirow{2}{*}{ Case 4} & \multirow{2}{*}{$\mathrm{Z} 2$} & Top flange & -2.93 & -2.76 & -2.90 & -0.17 & 0.95 & 5.79 \\
\hline & & Bottom flange & 3.20 & 3.09 & 4.60 & 0.11 & 0.67 & 3.41 \\
\hline
\end{tabular}

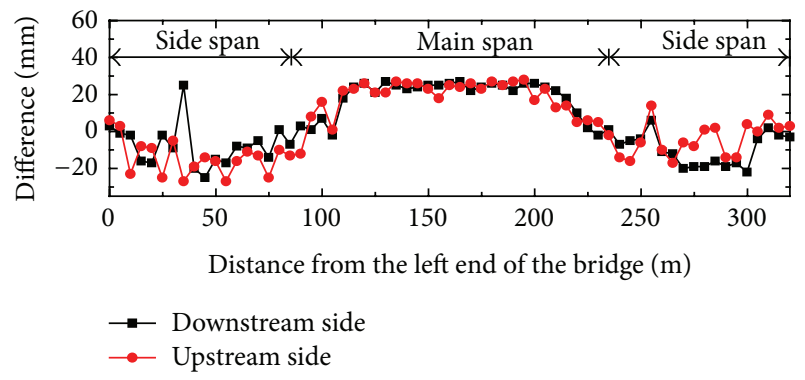

FIGURE 9: Differences between monitored and design elevations.

difference is $28 \mathrm{~mm}$, which is within the maximum permitted error of L/5000 (i.e., $30 \mathrm{~mm}$ ) [22].

3.3. Monitoring in the Completion Tests. The completion tests were conducted on January 14th, 2014, in which both static load tests and dynamic tests were made. In the static tests, there were four load cases, as shown in Table 3, where nine or ten trucks, each with a weight of $350 \mathrm{kN}$, were adopted. The front axle weight and the two rear axle weights of the trucks are $70 \mathrm{kN}$ and $140 \mathrm{kN}$, respectively; and the axle spacing is $350 \mathrm{~cm}$ and $135 \mathrm{~cm}$, respectively.

Taking the test results of the upstream girder as examples, the stress and deflection responses are illustrated in Tables 4 and 5, respectively. Both the check coefficients [22] of stress and deflection are all less than 1 , indicating that the structure has required bearing capacity and the vertical stiffness. In addition, the relative residual strain and deformation after unloading are less than $20 \%$, indicating that the box girder has desirable restoring ability subjected to the test loads, and the structure basically behaved linear elastically during the tests.

Dynamic load test used the typical pulse method [23]; that is, through collecting microvibration of bridge caused by ambient excitation, the dynamic characteristics of structure, such as vibration frequency, vibration mode, and damping ratio, are obtained. The layout of acceleration sensors is illustrated in Figure 6. Figure 10 shows two typical vibration modes with the corresponding frequencies of $1.11 \mathrm{~Hz}$ and $1.58 \mathrm{~Hz}$, respectively, which are, however, slightly larger than the design values (i.e., $1.02 \mathrm{~Hz}$ and $1.37 \mathrm{~Hz}$ ), indicating that the actual stiffness is larger than expected so that the analytical model should be updated accordingly. 
TABLE 5: Deflection analysis of test results (upstream side).

\begin{tabular}{lccccccc}
\hline Load test & $\begin{array}{c}\text { Monitored } \\
\text { section }\end{array}$ & $\begin{array}{c}\text { Total } \\
\text { deflection } \\
(\mathrm{mm})\end{array}$ & $\begin{array}{c}\text { Elastic } \\
\text { deflection } \\
(\mathrm{mm})\end{array}$ & $\begin{array}{c}\text { Theoretical } \\
\text { deflection } \\
(\mathrm{mm})\end{array}$ & $\begin{array}{c}\text { Residual } \\
\text { deflection } \\
(\mathrm{mm})\end{array}$ & $\begin{array}{c}\text { Check } \\
\text { coefficient }\end{array}$ & $\begin{array}{c}\text { Relative residual } \\
\text { deformation }(\%)\end{array}$ \\
\hline Case 1 & $\mathrm{B} 1$ & -16.75 & -15.34 & -21.7 & -1.41 & 0.71 & 8.42 \\
Case 3 & $\mathrm{Z} 1$ & -18.41 & -15.86 & -18.4 & -2.55 & 0.86 & 13.85 \\
Case 4 & $\mathrm{Z} 2$ & -45.63 & -42.13 & -58.5 & -3.50 & 0.72 & 7.67 \\
\hline
\end{tabular}

TABLE 6: Measured DAFs in different tests.

\begin{tabular}{lcccc}
\hline Test & Speed & $\begin{array}{c}\text { Amplitude } \\
(\mathrm{mm})\end{array}$ & $\begin{array}{c}\text { Static deflection } \\
(\mathrm{mm})\end{array}$ & \multicolumn{2}{c}{$\begin{array}{c}\text { Impact factor } \\
\text { Measured value }\end{array}$} \\
\hline \multirow{3}{*}{ Running } & $10 \mathrm{~km} / \mathrm{h}$ & 0.054 & & 1.001 \\
& $30 \mathrm{~km} / \mathrm{h}$ & 0.108 & & 1.016 \\
& $50 \mathrm{~km} / \mathrm{h}$ & 0.143 & 6.7 & 1.021 \\
\multirow{3}{*}{ Braking } & $10 \mathrm{~km} / \mathrm{h}$ & 0.117 & & 1.017 \\
& $30 \mathrm{~km} / \mathrm{h}$ & 0.095 & 1.014 & 1.025 \\
Jumping & $50 \mathrm{~km} / \mathrm{h}$ & 0.165 & - & - \\
\hline
\end{tabular}

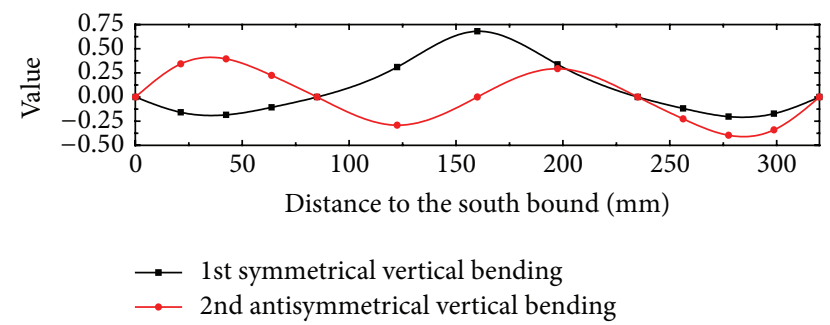

FIgUre 10: Typical tested bending modes.

The dynamic amplification factor (DAF) is another important parameter in bridge design, which was tested under different test circumstances. First, a truck with a weight of $350 \mathrm{kN}$ runs across the bridge at various constant speeds, and the deflection time-history at the midspan was recorded, as shown in Figure 11(a), in which the truck runs at a speed of $30 \mathrm{~km} / \mathrm{h}$. In the brake performance test, the same truck ran at the same speed but braked at the midspan. According to Figure 11(a), the deflection time-history is similar to that of the running test. Table 6 further shows that the DAFs in running tests are basically the same with the braking tests, and they changed little with the increase of vehicle speed. The maximum value of impact factor is 1.04 , which was in the jumping condition, as shown in Figure 11(b). However, it is still less than the design value of 1.05. In general, the dynamic deflection under vehicle moving deflection is small, showing the desirable dynamic deflection performance.

3.4. Monitoring during the Service Stage. Up to May, 2014, the SHM system of the bridge has been working for more than four and a half months. Figure 12 illustrates the timedependent deflections at different measuring points after the pavements were constructed. Note that the pavements were added to the decks about 1.5 months after the completion of the main structure. It is observed that from Figure 12(a) that the deflection fluctuates within a day [24], which is mainly due to the temperature changes in the day and night. Besides, the deflection in general becomes larger as time goes by, which is mainly due to shrinkage and creep of concrete. The deflections of midspan cross section of the main span increase by $15.10 \mathrm{~mm}$ and $26.73 \mathrm{~mm}, 3$ month and 6 month after the completion of construction, respectively. On the midspan and 1/4 cross sections of side span, as shown in Figure 12(b), the chambers are observed to increase with time, though they are much less than the deflections in Figure 12(a) because the side spans are significantly shorter than the main span.

Figure 13 illustrates the strain time-histories of the reinforcements at different locations of the bridge. Due to the electromagnetic noise (i.e., the noise inherent in typical data acquisition), there are a number of abnormal signals; however, when these data are filtered, the time-dependent changes could still be observed. According to Figure 13, there are still some daily fluctuations in strain data at all locations, which is probably due to the change in ambient temperature. For the reinforcing bar in the top flange of the main span support, as shown in Figure 13(a), the strain increment is insignificant indicating that concrete shrinkage or creep is not significant in this region, which is possibly due to the large reinforcement ratio and the stress condition at the bridge support. However, there is a mild increase in strain of the reinforcing bar in top flange of midspan section of the main span, as shown in Figure 13(b), showing that the creep effect might be more significant in this region. In general, due to the short monitoring period, the strain increments are not large at all monitoring points [25].

Shown in Figure 14 are the monitored temperature timehistories on June 29th, 2014, where the S-shape curves are observed and the temperatures also vary at different locations. The largest daily temperature fluctuation (from 


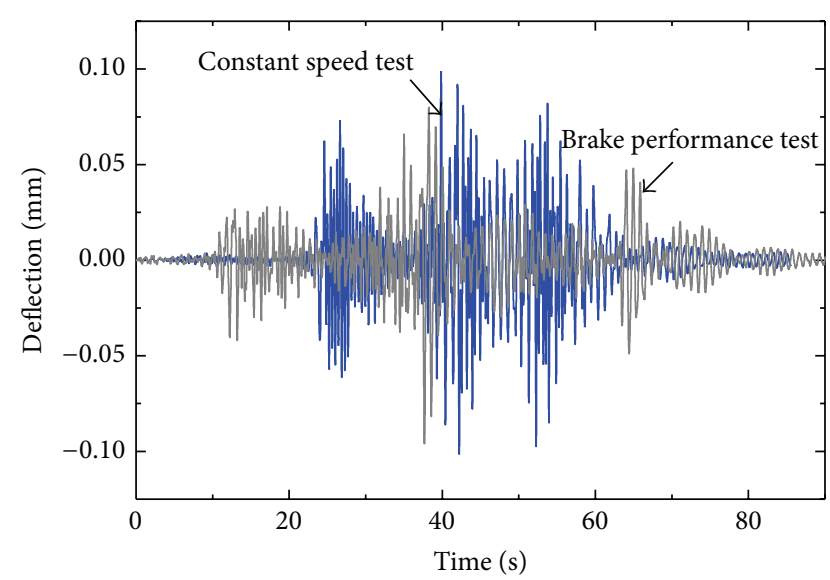

(a) Constant speed and brake performance tests $(30 \mathrm{~km} / \mathrm{h})$

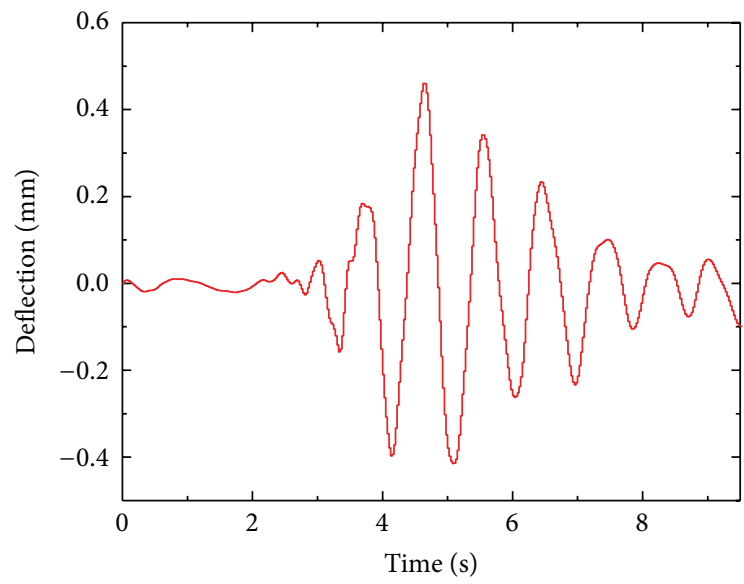

(b) Jumping test $(30 \mathrm{~km} / \mathrm{h})$

FIgURE 11: Deflection time-histories in dynamic tests.

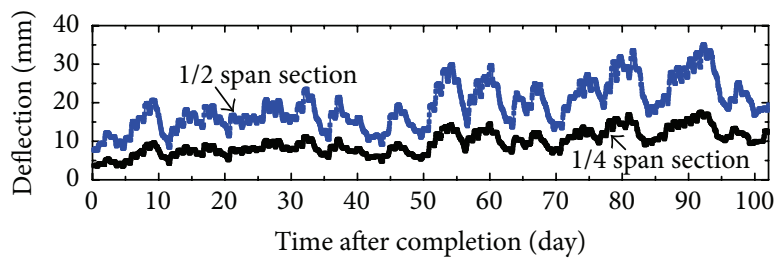

(a) Main span

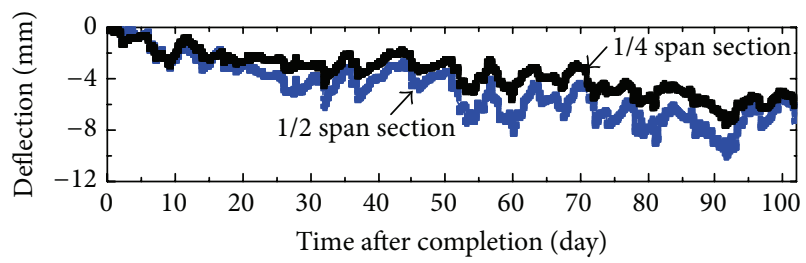

(b) Side span

FIGURE 12: Monitored deflection time-histories.

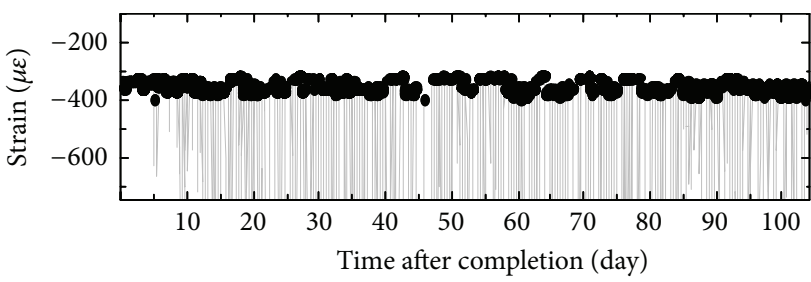

- Original data

- Filtered data

(a) In the top flange of the main span support

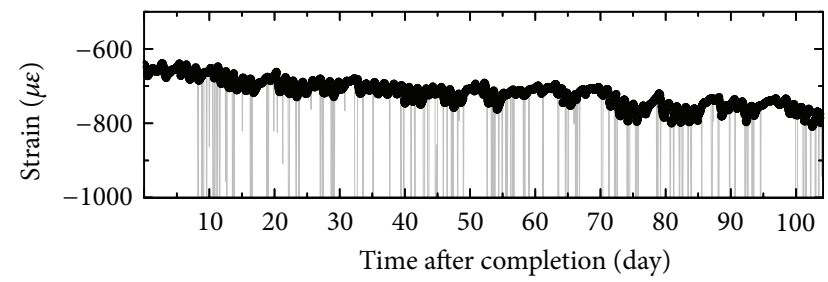

- Original data

- Filtered data

(b) In the top flange of the midspan cross section of the main span

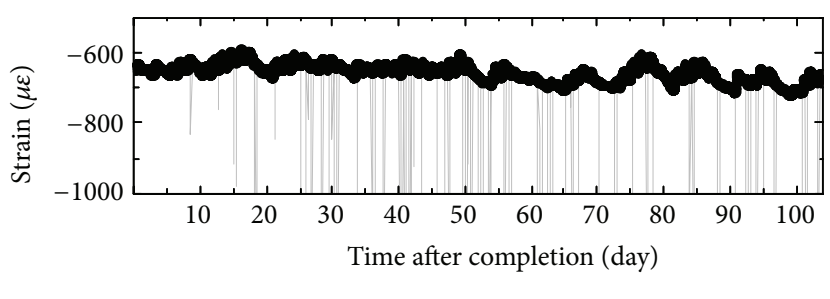

- Original data

- Filtered data

(c) In the bottom flange of the midspan cross section of the main span

FIgURE 13: Monitored strain time-histories. 


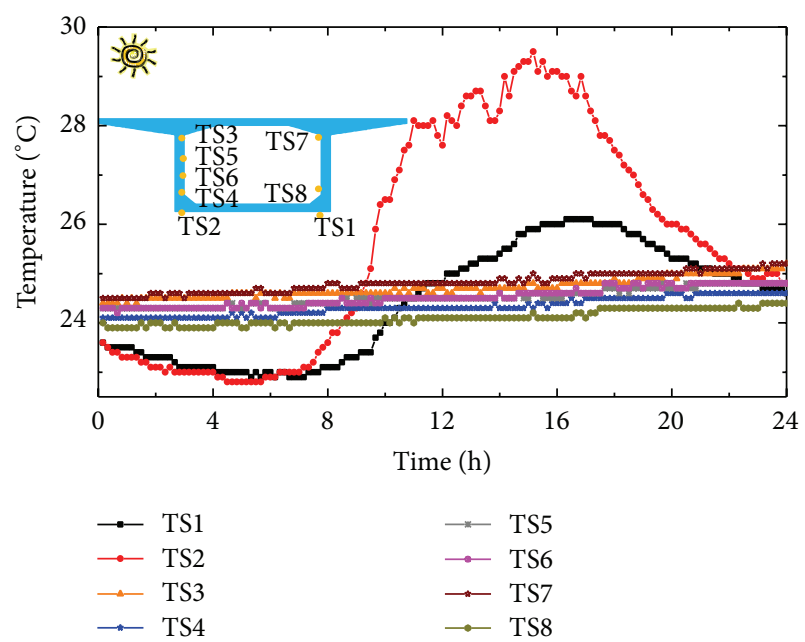

FIgURE 14: Monitored daily temperature time-histories.

$22.8^{\circ} \mathrm{C}$ to $29.5^{\circ} \mathrm{C}$ ) is found at the sensor TS2, which is at the south side of the bottom plates. For the sensor TS1, the largest daily temperature fluctuation is smaller than that of TS2 (i.e., $3.2^{\circ} \mathrm{C}$ ). On the other hand, the temperature fluctuation on the insides surfaces of the box girder is much less significant, and the largest variation is only $0.8^{\circ} \mathrm{C}$. Considering that temperature distribution plays a very important role on the short and long-term behavior of PSC box girders, it is necessary to perform such a long-term monitoring on the temperature distribution, based on which more rational analytical model could be obtained and updated.

\section{Conclusion}

For long-span PSC box girder bridges, their construction is usually a long and complex process, in which there are a number of structural alternations. During the service stage, however, their performance is also influenced by a number of time-variant factors such as concrete shrinkage, creep, and steel relaxation. As a result, the time-dependent behaviors of the PSC box girder bridges are complex. Therefore, it is of great importance to develop a life-cycle monitoring system using distributed sensor network, which is aimed at the most efficient use of sensors during construction, completion test, and long-term service. This paper presents a brief review on the state-of-art investigation on the SHM system of the PSC girder bridges. Strategies, methods, and emphasis of the monitoring on PSC bridges are discussed. A case study is made on a three-span PSC box girder bridge in China to demonstrate the proposed monitoring plan.

According to the monitored stress and deflection data during the construction, the monitored data in general agree well with the design values. Through dynamic adjustment during the construction, the differences are all within the threshold values; however, it is observed that, during the closure of bridge, the construction error might become larger than the other processes, indicating that these processes are the dominating ones in the entire construction.
Under the static load tests, the measured stresses and displacements are all below the design values. The residual stresses and displacements, after the loads were removed, were all very small, showing that the bridge performed elastically during the tests. According to the dynamic tests, the measured natural frequencies are larger than design, showing that the actual structure is stiffer than predicted. Therefore, the analytical model should be updated based upon the field monitored data. In the braking test, the measured DLA is 1.025 , so that the design value of 1.05 is reasonable for this bridge. No cracks were found during all the tests.

As to the long-term monitoring, the system effectively combines the sensors for construction monitoring and completion tests, so that the total costs are significantly reduced. The wireless data transmission system successfully sends the quasistatic data to the remote analysis center. However, it is found that the measured time-dependent deflections are larger than design values; considering that the continuous increase in deflection at midspan is one of the main problems of long-span PSC box girder bridges, a more accurate shrinkage and creep model is required in future study. In addition, the extension of the service life of sensors and possible replacement methods of the sensors are of crucial importance for the life-cycle monitoring.

\section{Conflict of Interests}

The authors declare that there is no conflict of interests regarding the publication of this paper.

\section{Acknowledgments}

The support from the Jiangsu Transportation Department under Grant no. 2011Y03, the Natural Science Foundation of Jiangsu under Grant no. BK2011611, the Education Department of Jiangsu under Grant no. JHB2012-1, and the Fok Ying Tung Education Foundation under Grant no. 131074 is gratefully acknowledged.

\section{References}

[1] C. Boller, F. Chang, and Y. Fujino, Structural Health MonitoringAn Introduction and Definition, John Wiley \& Sons, London, UK, 2009.

[2] A. Q. Li, Y. L. Ding, H. Wang, and T. Guo, "Analysis and assessment of bridge health monitoring mass data -progress in research/development of 'structural Health Monitoring", Science in China Series E: Technological Sciences, vol. 55, no. 8, pp. 2212-2224, 2012.

[3] T.-H. Yi, H.-N. Li, and M. Gu, "Recent research and applications of GPS-based monitoring technology for high-rise structures," Structural Control and Health Monitoring, vol. 20, no. 5, pp. 649670, 2013.

[4] T. H. Yi, H. N. Li, and M. Gu, "Optimal sensor placement for structural health monitoring based on multiple optimization strategies," Structural Design of Tall and Special Buildings, vol. 20, no. 7, pp. 881-900, 2011. 
[5] T.-H. Yi, H.-N. Li, and M. Gu, "Experimental assessment of high-rate GPS receivers for deformation monitoring of bridge," Measurement, vol. 46, no. 1, pp. 420-432, 2013.

[6] J. F. Liu and Q. W. Zhang, "Dynamic characteristics of a thousands-meter scale cable-stayed bridge," in Sensors and Smart Structures Technologies for Civil, Mechanical, and Aerospace Systems, vol. 7647 of Proceedings of SPIE, April 2010.

[7] D. Inaudi, "Long-term static structural health monitoring," in Proceedings of the Structures Congress, pp. 566-577, Orlando, Fla, USA, May 2010.

[8] S. M. Petroff, M. W. Halling, and P. J. Barr, "Monitoring of long term bridge performance (LTBP) program bridges," in Proceedings of the Structures Congress, pp. 65-76, 2011.

[9] C. Rodrigues, C. Felix, A. Lage, and J. Figueiras, "Development of a long-term monitoring system based on FBG sensors applied to concrete bridges," Engineering Structures, vol. 32, no. 8, pp. 1993-2002, 2010.

[10] H. M. Dwairi, M. C. Wagner, M. J. Kowalsky, and P. Zia, "Behavior of instrumented prestressed high performance concrete bridge girders," Construction and Building Materials, vol. 24, no. 11, pp. 2294-2311, 2010.

[11] M. L. Wang, "Long term health monitoring of post-tensioning box girder bridges," Smart Structures and Systems, vol. 4, no. 6, pp. 711-726, 2008.

[12] N. A. Hoult, P. R. A. Fidler, P. G. Hill, and C. R. Middleton, "Long-term wireless structural health monitoring of the ferriby road bridge," Journal of Bridge Engineering, vol. 15, no. 2, pp. 153$159,2010$.

[13] A. Cury, C. Cremona, and J. Dumoulin, "Long-term monitoring of a PSC box girder bridge: operational modal analysis, data normalization and structural modification assessment," Mechanical Systems and Signal Processing, vol. 33, pp. 13-37, 2012.

[14] H. Sousa, J. Bento, and J. Figueiras, "Construction assessment and long-term prediction of prestressed concrete bridges based on monitoring data," Engineering Structures, vol. 52, pp. 26-37, 2013.

[15] H. C. Gomez, P. J. Fanning, M. Q. Feng, and S. Lee, "Testing and long-term monitoring of a curved concrete box girder bridge," Engineering Structures, vol. 33, no. 10, pp. 2861-2869, 2011.

[16] W. Chung, S. Kim, N.-S. Kim, and H.-U. Lee, "Deflection estimation of a full scale prestressed concrete girder using longgauge fiber optic sensors," Construction and Building Materials, vol. 22, no. 3, pp. 394-401, 2008.

[17] I. N. Robertson, "Prediction of vertical deflections for a longspan prestressed concrete bridge structure," Engineering Structures, vol. 27, no. 12, pp. 1820-1827, 2005.

[18] Y. H. Li, Performance Analysis and Evolution of Continuous Rigid Frame Bridge Based on Long-Term Health Monitoring, South China University Technology, Guangzhou, China, 2012 (Chinese).

[19] G. Liu, Condition Assessment Research to Large-Span Bridges Based on Long-Term Static Monitoring Data, College of Civil Engineering of Chongqing University, Chongqing, China, 2010 (Chinese).

[20] Y. B. Huang, Study on practical health monitoring system and safety evaluation standard of long-span continuous rigidframe bridge [M.S. thesis], Chongqing Jiaotong University, Chongqing, China, 2012, (Chinese).

[21] Z. L. Lan, J. T. Zhou, and Z. X. Zhou, "Research of online monitoring system of box girder bridge deflections," Journal of Chongqing Jiaotong University, vol. 27, no. 4, pp. 525-528, 2008.
[22] The Ministry of Communications of the People's Republic of China, Quality Inspection and Evaluation Standard of Highway Engineering, China Communications Press, Beijing, China, 2004.

[23] W.-X. Ren, X.-L. Peng, and Y.-Q. Lin, "Experimental and analytical studies on dynamic characteristics of a large span cable-stayed bridge," Engineering Structures, vol. 27, no. 4, pp. 535-548, 2005.

[24] L. Sun, X. W. Hao, and D. L. Tan, "Health monitoring and assessment system design for large span continuous rigid frame bridges," Journal of Guangxi University, vol. 35, no. 4, pp. 621$626,2010$.

[25] J. Wang and Z. Fang, "Analysis and field measurement of concrete box girder bridges for shrinkage and creep effects," China Civil Engineering Journal, vol. 41, no. 1, pp. 70-81, 2008. 

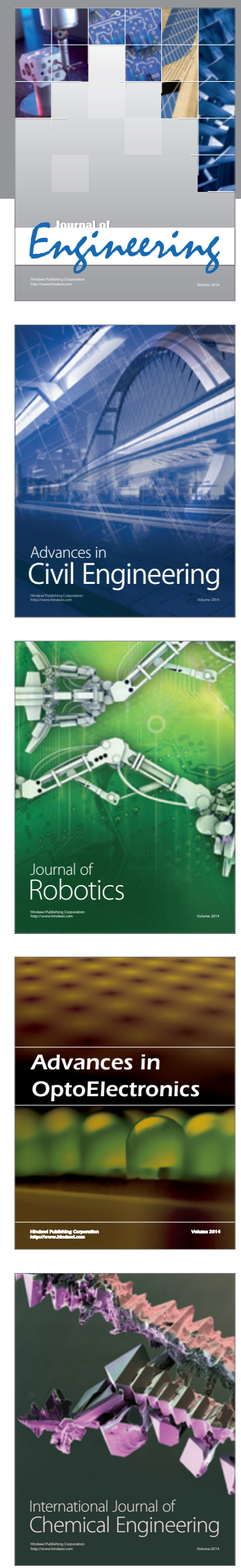

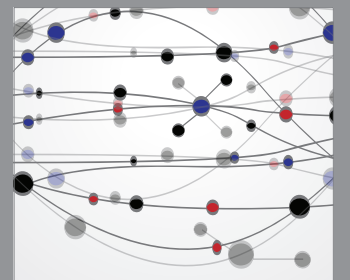

The Scientific World Journal
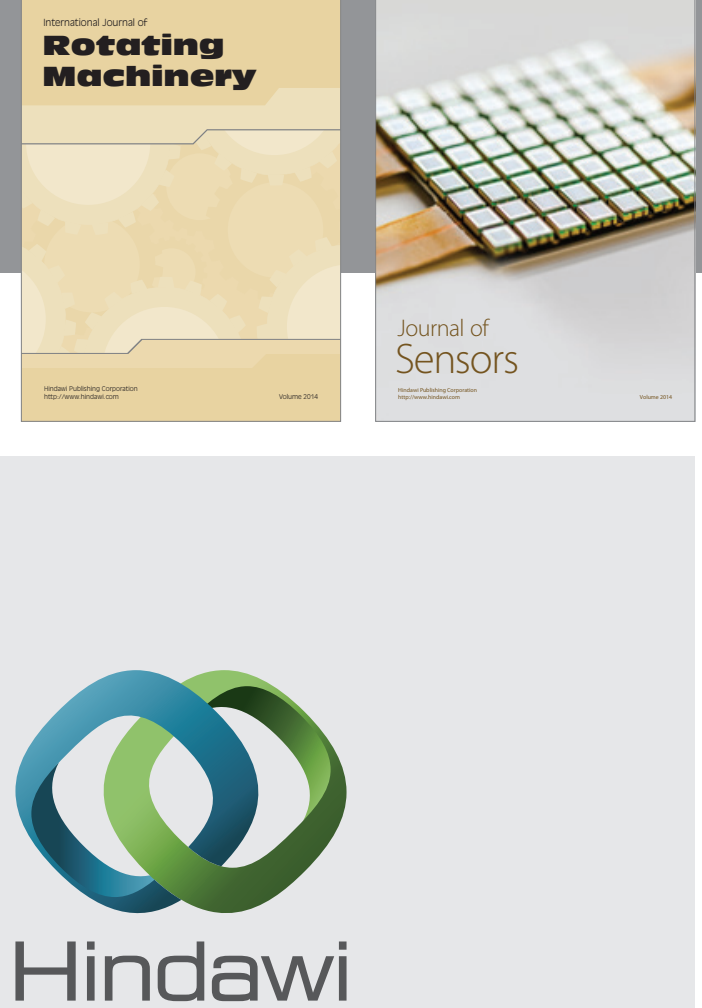

Submit your manuscripts at http://www.hindawi.com
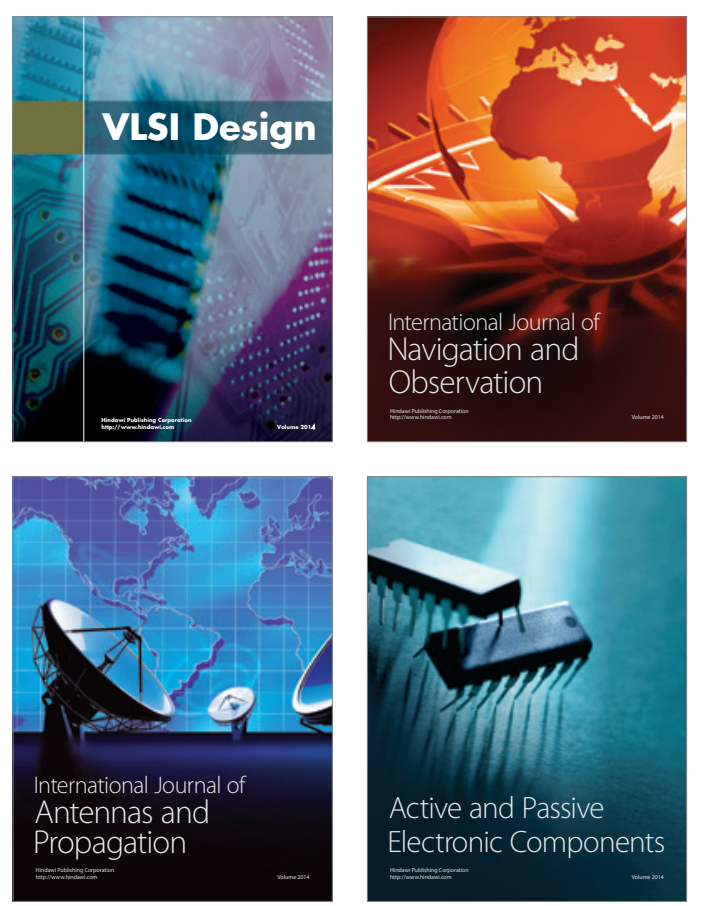
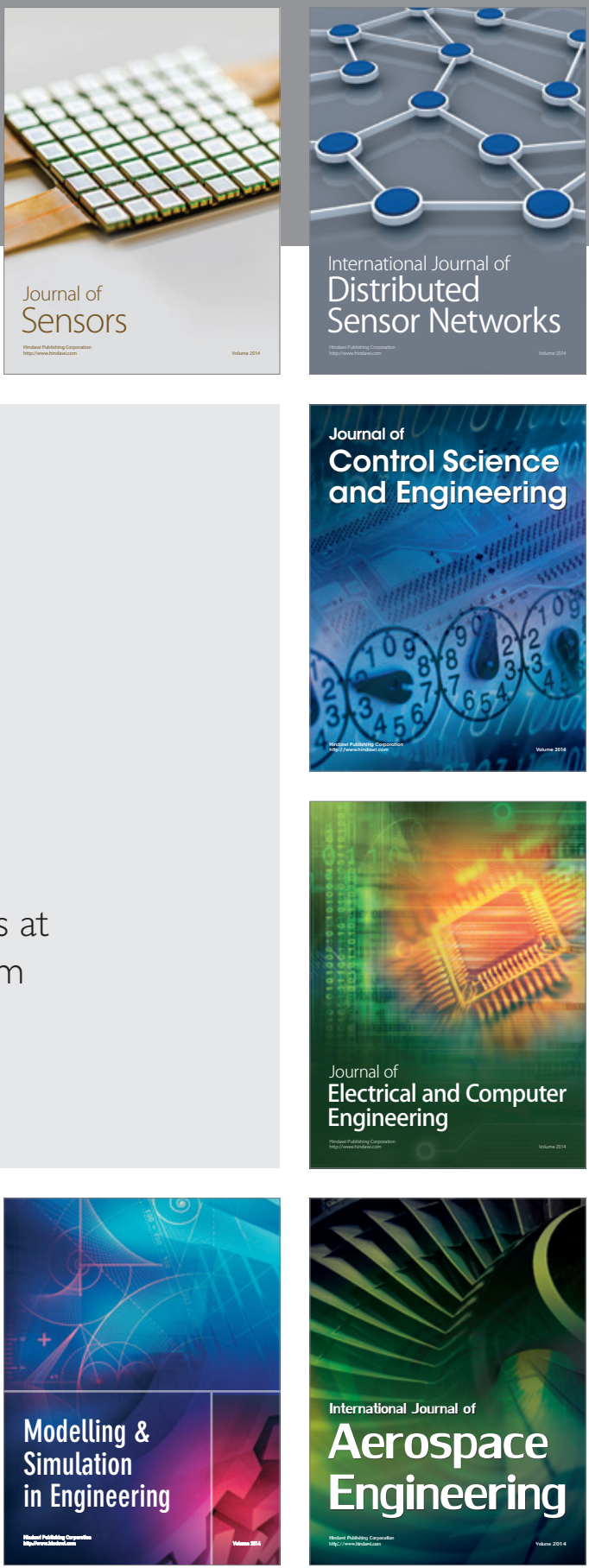

Journal of

Control Science

and Engineering
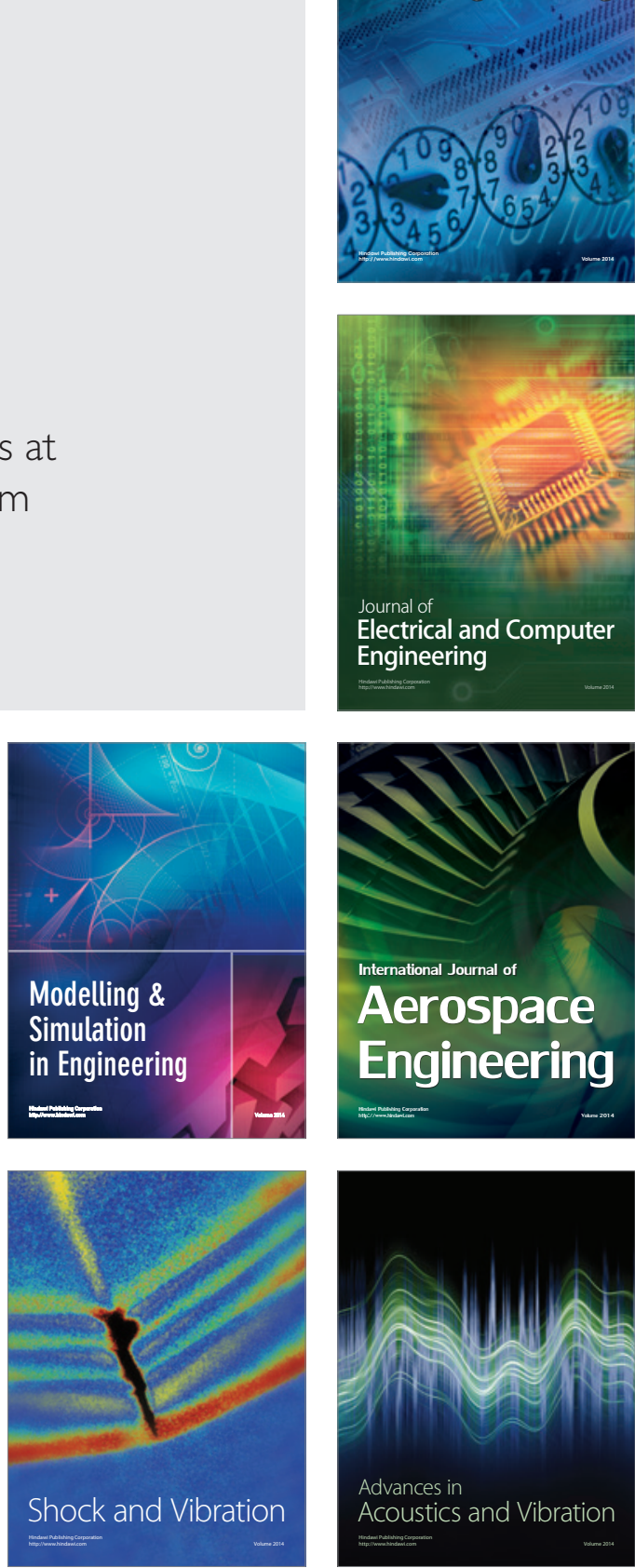